See discussions, stats, and author profiles for this publication at: https://www.researchgate.net/publication/282706163

\title{
Effects of feeding a spray-dried multivalent polyclonal antibody preparation on feedlot performance, feeding behavior, carcass characteristics, rumenitis, and blood gas profile of...
}

Article in Journal of Animal Science · October 2015

DOI: 10.2527/jas.2015-9227

CITATIONS

2

12 authors, including:

Danilo Millen

São Paulo State University (UNESP)

79 PUBLICATIONS 338 CITATIONS

SEE PROFILE

Nicolas Dilorenzo

University of Florida

121 PUBLICATIONS 648 CITATIONS

SEE PROFILE

Some of the authors of this publication are also working on these related projects:

Rumenology Book View project

Optimizing Ecosystem Services of Long-Term Grass-N and Legume-Based Grassland-Livestock Systems View project
READS

72

Robson Pacheco

Universidade do Extremo Sul Catarinense (UNESC)

19 PUBLICATIONS 223 CITATIONS

SEE PROFILE

Cyntia Ludovico Martins

São Paulo State University

56 PUBLICATIONS 295 CITATIONS

SEE PROFILE 


\title{
Effects of feeding a spray-dried multivalent polyclonal antibody preparation on feedlot performance, feeding behavior, carcass characteristics, rumenitis, and blood gas profile of Brangus and Nellore yearling bulls ${ }^{1}$
}

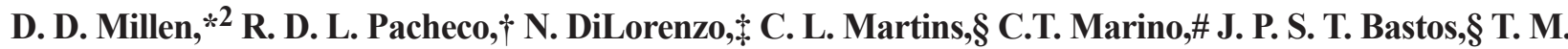 \\ Mariani,§ R. S. Barducci,§ L. M. N. Sarti,§ A. DiCostanzo,|| P. H. M. Rodrigues,\# and M. D. B. Arrigoni§ \\ *Animal Science College, São Paulo State University (UNESP), Dracena, São Paulo, \\ Brazil 17900-000; †Mato Grosso State Agricultural and Extension Service, Varzea Grande, Mato \\ Grosso, Brazil 78115-1000; §Veterinary Medicine and Animal Science College, São Paulo State University \\ (UNESP), Botucatu, São Paulo, Brazil 18618-000; \#Department of Animal Nutrition and Production, University of \\ São Paulo, Pirassununga, São Paulo, Brazil 13635-900; \$North Florida Research and Education Center, University \\ of Florida, Marianna 32446; and ||Department of Animal Science, University of Minnesota, Saint Paul 55108
}

\begin{abstract}
The objective of this study was to evaluate the effects of replacing monensin (MON) with a spray-dried multivalent polyclonal antibody preparation (PAP) against several ruminal microorganisms on feedlot performance, carcass characteristics, feeding behavior, blood gas profile, and the rumenitis incidence of Brangus and Nellore yearling bulls. The study was designed as a completely randomized design with a $2 \times 2$ factorial arrangement, replicated 6 times $(4$ bulls per pen and a total of 24 pens), in which bulls ( $n=$ 48) of each biotype were fed diets containing either MON fed at $300 \mathrm{mg} / \mathrm{d}$ or PAP fed at $3 \mathrm{~g} / \mathrm{d}$. No significant feed additive main effects were observed for ADG $(P=0.27), \mathrm{G}: \mathrm{F}(P=0.28), \mathrm{HCW}(P=0.99)$, or dressing percentage $(P=0.80)$. However, bulls receiving PAP had greater DMI $(P=0.02)$ and larger $(P=$ $0.02)$ final LM area as well as greater $(P<0.01)$ blood concentrations of bicarbonate and base excess in the extracellular fluid than bulls receiving MON. Brangus bulls had greater $(P<0.01)$ ADG and DMI expressed
\end{abstract}

in kilograms, final BW, heavier HCW, and larger initial and final LM area than Nellore bulls. However, Nellore bulls had greater daily DMI fluctuation $(P<$ $0.01)$, expressed as a percentage, and greater incidence of rumenitis $(P=0.05)$ than Brangus bulls. In addition, Brangus bulls had greater $(P<0.01)$ DMI per meal and also presented lower $(P<0.01) \mathrm{DM}$ and NDF rumination rates when compared with Nellore bulls. Significant interactions $(P<0.05)$ between biotype and feed additive were observed for SFA, unsaturated fatty acids (UFA), MUFA, and PUFA concentrations in adipose tissues. When Nellore bulls were fed PAP, fat had greater $(P<0.05)$ SFA and PUFA contents but less $(P<0.01)$ UFA and MUFA than Nellore bulls receiving MON. For Brangus bulls, MON led to greater $(P<$ $0.05)$ SFA and PUFA and less $(P<0.05)$ UFA and MUFA than Brangus bulls fed PAP. Feeding a spraydried PAP led to similar feedlot performance compared with that when feeding MON. Spray-dried PAP might provide a new technology alternative to ionophores.

Key words: Brangus, feedlot, monensin, Nellore, polyclonal antibody

\section{INTRODUCTION}

\footnotetext{
${ }^{1}$ Financial support was provided by FAPESP (São Paulo Research Foundation, São Paulo, São Paulo, Brazil).

${ }^{2}$ Corresponding author: danilomillen@dracena.unesp.br Received April 22, 2015.

Accepted July 8, 2015.
}

Certain European nations have banned the use of ionophores such as monensin (MON), classifying them as antibiotics (European Parliament, Council of the European Union, 2003). This has instigated a search for replacements for ionophores (Castillo et al., 2004; Meyer et al., 2009; Anassori et al., 2011). 
One alternative to ionophores that has been evaluated in vivo recently is passive immunization (DiLorenzo et al., 2008; Blanch et al., 2009). Vaccination and oral doses of antibodies against lactate-producing ruminal bacteria have led to a reduction in concentration of rumen lactate (Shu et al., 1999), greater ruminal pH (DiLorenzo et al., 2006), and greater DMI (Gill et al., 2000; Shu et al., 2000). In addition, feeding a multivalent polyclonal antibody preparation (PAP) against several ruminal microorganisms led to feedlot performance of yearling bulls similar to that of bulls receiving MON (Pacheco et al., 2012). Furthermore, rumenitis scores of bulls receiving a multivalent PAP were lower than for bulls receiving MON. Marino et al. (2011) reported that feeding multivalent PAP was as effective as MON at increasing ruminal $\mathrm{pH} \mathrm{2,4}$, and $6 \mathrm{~h}$ after feeding.

The PAP trials described above used oral doses of a liquid PAP product that was top-dressed onto the diet. Use of liquid supplements involves higher freight costs and a reduced shelf life. Use of a powder form of PAP should facilitate the feeding management, as it could increase shelf life and allow inclusion in mineral supplements. The objective of this study was to evaluate performance response to replacing MON with a spray-dried multivalent PAP against several ruminal microorganisms and immunogens. Carcass characteristics, feeding behavior, blood gas profiles, and rumenitis of Brangus and Nellore yearling bulls fed high-concentrate diets were monitored. Because internal and external fat depots may differ in composition (Waldman et al., 1968), their interactions with different breeds and feed additives were evaluated as well.

\section{MATERIALS AND METHODS}

Animals care procedures followed guidelines established by the São Paulo State University Ethical Committee for Animal Research (CONCEA, 2013) .

\section{Polyclonal Antibody Preparations}

Procedures for preparation of PAP followed those described by DiLorenzo et al. (2006) except that a multivalent PAP was tested (Pacheco et al., 2012) instead of a preparation containing only a single antibody. In addition, the liquid product containing the polyclonal antibodies was spray dried with hot air to form a powder. Polyclonal antibodies (RMT Optimize) were produced by CAMAS Inc. (Le Center, MN). The commercial product contains immunoglobulins with approximately $26 \%$ of antibodies being active against Streptococcus bovis (ATCC 9809), 12\% against Fusobacterium necrophorum (ATCC 27852), and $48 \%$ against proteolytic bacteria Clostridium sticklandii (ATCC 12662), Clostridium aminophilum (ATCC 49906), or Peptostreptococcus anaerobius (ATCC 49031). The remaining antibodies (14\%) had activities against Escherichia coli O157:H7 (ATCC 43895). Streptococcus bovis is a primary lactic acid-producing bacteria of ruminants and Fusobacterium necrophorum is involved with the development of liver abscesses in acidotic cattle. Clostridium sticklandii, Clostridium aminophilum, and Peptostreptococcus anaerobius are hyperammonia-producing bacteria. Escherichia coli O157:H7 is a foodborne pathogen that dwells in the rumen and terminal rectum of bovine species.

\section{Animals and Management Description}

The study was performed at the São Paulo State University feedlot, Botucatu campus, Brazil, with 96 7-mo-old yearling bulls (48 Nellore and 48 Brangus [five-eighths Red Angus $\times$ three-eighths Nellore]) housed in 24 pens ( 5 by $5.35 \mathrm{~m} ; n=4$ bulls per pen). Mean initial BW was $257.8 \pm 14.7$ and $310.9 \pm 13.5 \mathrm{~kg}$ for the Nellore and Brangus bulls, respectively. All bulls came from the same ranch and pastures, and all had the same nutritional background.

At arrival, bulls were dewormed, vaccinated (tetanus, bovine viral diarrhea virus, and 7-way Clostridium spp.; Cattlemaster and Bovishield; Pfizer Animal Health, New York, NY) and subsequently adapted to pens and diets during a 4-wk period, when a $55 \%$ concentrate diet was fed (Table 1), before dietary additives were applied.

Feed ingredients were mixed in a truck-mounted mixer. Bulls were fed for ad libitum intake twice daily throughout the study with fresh feed added at 0800 (40\% of total ration) and $1500 \mathrm{~h}$ ( $60 \%$ of total ration). The ration was delivered to a feed bunk $(5 \mathrm{~m}$, with $1.25 \mathrm{~m}$ per bull for each pen). The amount of fresh feed added was adjusted daily based on the amount of feed refusals remaining before the morning feed delivery (at $0700 \mathrm{~h}$ ). Refused feed was discarded daily. Bulls had free-choice access to water troughs $(0.89$ by 1.00 by $1.00 \mathrm{~m})$.

\section{Treatments and Diets}

The study was a completely randomized design with a $2 \times 2$ factorial arrangement of treatments, replicated 6 times ( 4 bulls per pen, total of 24 pens), in which 48 bulls of each biotype were fed diets supplemented with either MON (Rumensin; Elanco Animal Health, Indianapolis, IN) fed at $300 \mathrm{mg} / \mathrm{d}$ or PAP (RMT Optimize; CAMAS Inc.) fed at $3 \mathrm{~g} / \mathrm{d}$, both via a feed-mixed supplement. A new batch of supplement containing either PAP or MON was prepared daily just before the morning feed delivery to reach the target levels described. The study was 
Table 1. Feed ingredients and chemical composition of high-concentrate diets fed to yearling beef bulls

\begin{tabular}{|c|c|c|c|}
\hline \multirow[b]{2}{*}{ Item } & \multicolumn{3}{|c|}{ Period } \\
\hline & Adaptation & Growing & Finishing \\
\hline Days fed & 28 & 56 & 56 \\
\hline \multicolumn{4}{|l|}{ Ingredient, $\%$ of DM } \\
\hline Coast cross hay & 16.4 & 3.3 & 5.7 \\
\hline Sugarcane bagasse & 28.4 & 26.7 & 9.4 \\
\hline High-moisture corn grain $(72 \% \mathrm{DM})$ & 16.4 & 19.6 & 31.9 \\
\hline Corn grain cracked ${ }^{1}$ & 10.4 & 15.6 & 8.4 \\
\hline Citrus pulp pellets & 9.0 & 15.0 & 32.4 \\
\hline Soybean meal (44\% CP) & 17.9 & 18.3 & 10.5 \\
\hline Loose, dry supplement ${ }^{2}$ & 1.5 & 1.5 & 1.7 \\
\hline \multicolumn{4}{|l|}{ Nutrient content, $\%$ of DM } \\
\hline $\mathrm{DM}, \%$ & 74.0 & 73.0 & 71.0 \\
\hline TDN & 69.0 & 72.0 & 78.0 \\
\hline $\mathrm{NEg}, \mathrm{Mcal} / \mathrm{kg}$ of $\mathrm{DM}^{3}$ & 0.99 & 1.08 & 1.24 \\
\hline Total nonfiber carbohydrate ${ }^{3}$ & 42.2 & 47.0 & 58.6 \\
\hline $\mathrm{CP}$ & 16.8 & 15.6 & 13.2 \\
\hline $\mathrm{RDP}^{3}$ & 12.1 & 11.7 & 10.0 \\
\hline Ether extract ${ }^{4}$ & 3.3 & 3.6 & 3.8 \\
\hline $\mathrm{NDF}$ & 36.4 & 30.2 & 20.4 \\
\hline $\mathrm{Ca}^{4}$ & 0.46 & 0.54 & 0.89 \\
\hline $\mathrm{P}^{4}$ & 0.34 & 0.35 & 0.32 \\
\hline
\end{tabular}

${ }^{1}$ Geometric mean diameter $=3.6 \mathrm{~mm}$.

${ }^{2}$ Supplement contained $30 \%$ urea as a $\mathrm{N}$ source as well as $26.7 \% \mathrm{Ca}$, $5.3 \% \mathrm{P}, 10.9 \% \mathrm{Na}, 1.5 \% \mathrm{~S}, 2,600 \mathrm{mg} / \mathrm{kg} \mathrm{Zn}, 1,300 \mathrm{mg} / \mathrm{kg} \mathrm{Mn}, 1,032 \mathrm{mg} /$ $\mathrm{kg} \mathrm{Cu}, 45.0 \mathrm{mg} / \mathrm{kg} \mathrm{I}, 15.0 \mathrm{mg} / \mathrm{kg} \mathrm{Se}, 154 \mathrm{mg} / \mathrm{kg} \mathrm{Co}$, and 2,500 mg/kg $\mathrm{Fe}$. Monensin and polyclonal antibody preparation were included into the supplement only during the growing and finishing periods.

${ }^{3}$ Estimated from book values for ingredients (NRC, 2000).

${ }^{4}$ Ether extract was determined gravimetrically after extraction using petroleum ether in a Soxhlet extractor (method 920.85; AOAC, 1990). Calcium and $\mathrm{P}$ were determined according to methods 968.08 (AOAC, 1995) and 965.17 (AOAC, 1990), respectively.

designed to evaluate the effects of replacing MON with PAP, so a negative control group was not used.

Cattle were moved through a total of 3 feeding periods for this study: adaptation, growing, and finishing. Longissimus muscle area and rib fat thickness were measured via ultrasound in the beginning and at the end of the growing and finishing periods following a method described by Perkins et al. (1992). A single trained technician collected and read all images, which were collected using an Aloka SSD-1100 Flexus realtime ultrasound unit (Aloka Co. Ltd., Tokyo, Japan) with a $17.2-\mathrm{cm} 3.5-\mathrm{MHz}$ probe. Diets fed in the adaptation, growing, and finishing periods contained 55 , 70 , and $85 \%$ concentrate, respectively, and were composed of coast cross hay (Cynodon dactylon), sugarcane bagasse, high-moisture rolled corn grain, cracked corn grain, pelleted citrus pulp, soybean meal, and a mineral supplement (Table 1). Diets were formulated to match nutrient requirements specified by the NRC (2000) for ADG of $1.4 \mathrm{~kg}$.
A $55 \%$ concentrate diet was fed the first 28 -d period to adapt bulls to their subsequent diets. At the conclusion of adaptation, bulls were switched to the growing ( $70 \%$ concentrate) period. Criteria to shift to finishing diet $(85 \%$ concentrate) were based on ultrasound-derived 12th-rib fat thickness measurements. When bulls reached a minimum threshold of $3 \mathrm{~mm}$ of 12th-rib fat thickness, based on the average across all treatment groups, cattle were switched from the growing to the finishing period. Daily DMI was recorded by weighing feed offered $(0800 \mathrm{~h})$ and refused $(0700 \mathrm{~h}$ the following morning) within each pen and expressed in kilograms and as a percentage of mean BW during the growing and finishing periods. Cattle were weighed at the beginning and end of growing and finishing periods, during which feedlot performance, feeding behavior, blood gas profile, blood lipoproteins profile, and ultrasound measures were collected. Feed was withheld $16 \mathrm{~h}$ before each BW assessment. Bulls were harvested $(n=96$; 4 bulls per pen) when 12th-rib fat thickness of $4 \mathrm{~mm}$ was achieved based on the average across all treatment groups, as assessed by ultrasound, to achieve minimum fat cover for Brazilian market requirements. Final BW was obtained before transporting bulls for $64 \mathrm{~km}$ to the commercial abattoir (approximately $2 \mathrm{~h}$ ), where HCW was obtained after KPH fat removal. Dressing percentage was calculated by dividing HCW by final BW.

Diets were sampled weekly with samples analyzed immediately for DM and CP (methods 930.15 and 990.02, respectively; AOAC, 1997) and for NDF and ADF as described by Pacheco et al. (2012). Moreover, samples of diets and feed refusals collected during the 24-h feeding behavior measurements were analyzed for DM and NDF as described.

\section{Dry Matter Intake Fluctuations}

Daily DMI fluctuation was calculated for each pen as the difference in intake between consecutive days within each period (Bevans et al., 2005). Daily DMI fluctuation was expressed in kilograms and as variation according to the following formula: DMI fluctuation in kilograms/ DMI of the previous day in kilograms $\times 100$. The final data from each pen represented the average daily DMI fluctuation for each feeding period: growing and finishing.

\section{Feeding Behavior}

Data collection of behavior was made visually twice during the study, $20 \mathrm{~d}$ after the beginning of the growing and finishing feeding periods, according to Robles et al. (2007). Feeding behavior data were recorded every 5 min during 24-h period for each animal as follows: time spent eating (EAT), time spent ruminating 
(RUM), and time spent resting, expressed in minutes, and number of meals per day. Also, DMI and NDF intake for each pen were measured on the day data were collected. Meal length in minutes was calculated by dividing EAT by number of meals per day. Dry matter intake per meal in kilograms was calculated by dividing DMI by number of meals per pen each day. Also, EAT and RUM data were used to calculate DM consumption rate (DMCR; EAT/DMI) and DM rumination rate (RUM/DMI) expressed in minutes per kilogram of DM as well as NDF consumption rate (NDFCR; EAT/NDF intake) and NDF rumination rate (RUM/NDF intake) expressed in minutes per kilogram of NDF.

\section{Blood Gas and Blood Lipoproteins Profiles}

Blood samples were collected twice during the study: on d 15 of the growing and finishing periods. Blood samples immediately were placed on ice and analyzed within $2 \mathrm{~h}$ of collection. For blood gas profile, jugular venous whole blood was collected in 1-mL syringes containing sodium heparin $3 \mathrm{~h}$ after the morning feed delivery. The following blood parameters were determined with a $\mathrm{pH} /$ blood gas analyzer (BAYER Rapid Lab 865; Siemens Healthcare Diagnostics Inc., Deerfield, IL) as described by Brossard et al. (2003): $\mathrm{pH}$, bicarbonates $\left(\mathrm{HCO}_{3}\right)$, total $\mathrm{CO}_{2}$ content $\left(\mathbf{T C O} \mathbf{O}_{2}\right)$, base excess in whole blood (BEB), and base excess in extracellular fluid (BEECF). For blood lipoproteins profile, jugular venous whole blood was collected in $10-\mathrm{mL}$ vacuum tubes (BD Vacutainer, Franklin Lakes, NJ) that contained sodium heparin. Cholesterol, high-density lipoprotein (HDL), and triglyceride concentrations were determined by using commercial enzymatic kits (Laborlab, Guarulhos, São Paulo, Brazil) as described by Allain et al. (1974). The concentration of very-low-density lipoprotein (VLDL) was calculated by dividing the triglyceride concentration by 5 . Low-density lipoprotein (LDL) concentration was calculated as LDL $=$ cholesterol $-(\mathrm{HDL}+\mathrm{VLDL})$.

\section{Meat Cholesterol}

After $24 \mathrm{~h}$ at $0^{\circ} \mathrm{C}$, a 2.54-cm-thick steak sample from the LM of each carcass was harvested between 12th and 13th ribs and vacuum-packaged for meat cholesterol analysis as described by Folch et al. (1957) and Bohac et al. (1988).

\section{Rumenitis and Liver Abscess Incidences}

Rumenitis was assessed after bulls were eviscerated and entire rumen contents washed. Rumen epithelium was classified according to the incidence of lesions (rumenitis) and abnormalities (e.g., papillae clumped) as described by Bigham and McManus (1975) using a scale of 0 (no lesions and abnormalities noted) to 10 (severe ulcerative lesions). All rumens were scored by 2 trained individuals who were blind to the treatments, and final data represented the average of the 2 scores. Livers were scored for severity of abscesses using the system reported by Brink et al. (1990).

\section{Fatty Acids Profile}

After $24 \mathrm{~h}$ of carcass chill, 3-g adipose tissue samples from 3 different sites were harvested: 1) subcutaneous (s.c.) from LM between 11th and 12th ribs, 2) pelvic, and 3) intermuscular (between biceps femoris and gluteus medius muscles). After harvest, samples were immediately frozen in liquid nitrogen at $-196^{\circ} \mathrm{C}$ and transported in a nitrogen tank to the São Paulo State University Meat Lab (Botucatu, Brazil) for fatty acids profile assays. After thawing, the s.c. adipose tissue samples were reduced to paste with a Robot Coupe R301 Ultra food processor (Robot-coupe, Burgundy, France). A 400-mg sample, including connective tissue, was homogenized in the chloroform-methanol mix with an Ultra Turrax (IKA Works Inc., Artur Nogueira, Brazil) and filtered (Whatman paper number 4; SigmaAldrich, St. Louis, MO) to remove residual connective tissue. Fatty acids were measured as described by Noci et al. (2005) and Pacheco et al. (2012).

\section{Statistical Analysis}

Rumenitis scores were analyzed as nonparametric data by the NPAR1WAY procedure of SAS (SAS Inst., Inc., Cary, NC) and the Kruskal-Wallis test was used to compare means. Hot carcass weight, dressing percentage, and kidney-pelvic fat were analyzed as completely randomized design with a $2 \times 2$ factorial arrangement using the MIXED procedure of SAS and the Tukey test to compare means. The models included the main effects of biotypes (Brangus and Nellore), feed additive (PAP and $\mathrm{MON})$, and the biotype $\times$ feed additive interaction.

Feedlot performance, ultrasound measurements, feeding behavior, blood gas profile, and blood lipoproteins profile were analyzed as repeated measures using the MIXED procedure of SAS and the Tukey test to compare means. Period was included as the REPEATED option of SAS, with pen as the subject. The model included feed additive, biotype, biotype $\times$ feed additive, period (growing and finishing), period $\times$ biotype, period $\times$ feed additive, and period $\times$ biotype $\times$ feed additive. The fatty acid profile was analyzed as described for the feedlot performance but replacing period with site of fat harvest. Each variable analyzed as repeated measures was subjected to 8 covariance structures: unstruc- 
Table 2. Effect of 2 biotypes (Nellore and Brangus [five-eighths Red Angus and three-eighths Nellore]) provided monensin $(\mathrm{MON})$ or polyclonal antibody preparation (PAP) on feedlot performance and carcass characteristics of yearling beef bulls consuming high-concentrate diets during the growing and finishing periods $(n=24)$

\begin{tabular}{|c|c|c|c|c|c|c|c|c|c|c|}
\hline \multirow[b]{2}{*}{ Variable } & \multicolumn{2}{|c|}{ Biotype (BT) } & \multicolumn{2}{|c|}{ Feed additive $^{1}(\mathrm{FA})$} & \multicolumn{2}{|c|}{ Period $^{2}$} & \multirow[b]{2}{*}{ SEM } & \multicolumn{3}{|c|}{$P$-value } \\
\hline & Brangus & Nellore & PAP & $\mathrm{MON}$ & GRO & FNS & & BT & FA & Period \\
\hline \multicolumn{11}{|l|}{ Feedlot performance } \\
\hline Initial BW, kg & $310.9^{\mathrm{a}}$ & $257.8^{\mathrm{b}}$ & 283.8 & 284.9 & $281.2^{\mathrm{b}}$ & $357.0^{\mathrm{a}}$ & 6.80 & $<0.01$ & 0.88 & $<0.01$ \\
\hline Final BW, kg & $470.3^{\mathrm{a}}$ & $385.0^{\mathrm{b}}$ & 428.0 & 427.3 & $357.0^{\mathrm{b}}$ & $427.6^{\mathrm{a}}$ & 8.52 & $<0.01$ & 0.93 & $<0.01$ \\
\hline $\mathrm{ADG},{ }^{3} \mathrm{~kg}$ & 1.42 & 1.15 & 1.30 & 1.27 & 1.30 & 1.27 & 0.022 & $<0.01$ & 0.27 & 0.16 \\
\hline Daily DMI, ${ }^{3} \mathrm{~kg}$ & 8.36 & 6.49 & $7.60^{\mathrm{a}}$ & $7.24^{\mathrm{b}}$ & 6.76 & 8.08 & 0.14 & $<0.01$ & 0.02 & $<0.01$ \\
\hline Daily DMI, ${ }^{3} \%$ of BW & 2.14 & 2.00 & $2.11^{\mathrm{a}}$ & $2.03^{\mathrm{b}}$ & 2.10 & 2.04 & 0.021 & $<0.01$ & $<0.01$ & 0.03 \\
\hline $\mathrm{G}: \mathrm{F}, \mathrm{kg} / \mathrm{kg}$ & 0.172 & 0.179 & 0.173 & 0.178 & $0.194^{\mathrm{a}}$ & $0.157^{\mathrm{b}}$ & 0.0034 & 0.14 & 0.28 & $<0.01$ \\
\hline Daily DMI fluctuation, $\mathrm{kg}$ & 0.51 & 0.53 & 0.53 & 0.52 & 0.54 & 0.51 & 0.012 & 0.34 & 0.50 & 0.07 \\
\hline Daily DMI fluctuation, \% & $7.67^{\mathrm{b}}$ & $10.30^{\mathrm{a}}$ & 9.00 & 9.02 & $10.28^{\mathrm{a}}$ & $7.70^{\mathrm{b}}$ & 0.23 & $<0.01$ & 0.87 & $<0.01$ \\
\hline \multicolumn{11}{|l|}{ Carcass characteristics } \\
\hline $\mathrm{HCW}, \mathrm{kg}$ & $251.1^{\mathrm{a}}$ & $206.1^{\mathrm{b}}$ & 228.6 & 228.6 & - & - & 3.25 & $<0.01$ & 0.99 & - \\
\hline Dressing percentage & 52.8 & 52.9 & 52.9 & 52.8 & - & - & 0.25 & 0.63 & 0.80 & - \\
\hline Kidney-pelvic fat, $\mathrm{kg}$ & $4.23^{\mathrm{a}}$ & $3.22^{\mathrm{b}}$ & 3.71 & 3.73 & - & - & 0.38 & 0.02 & 0.95 & - \\
\hline Kidney-pelvic fat, $\%$ of $\mathrm{HCW}$ & 1.69 & 1.54 & 1.61 & 1.62 & - & - & 0.16 & 0.38 & 0.97 & - \\
\hline Initial LM area, ${ }^{4} \mathrm{~cm}^{2}$ & $59.3^{\mathrm{a}}$ & $48.1^{\mathrm{b}}$ & 54.5 & 52.9 & 49.4 & 58.0 & 1.05 & $<0.01$ & 0.13 & $<0.01$ \\
\hline Final LM area, $\mathrm{cm}^{2}$ & $68.8^{\mathrm{a}}$ & $57.6^{\mathrm{b}}$ & $64.5^{\mathrm{a}}$ & $61.8^{\mathrm{b}}$ & $58.0^{\mathrm{b}}$ & $68.3^{\mathrm{a}}$ & 1.08 & $<0.01$ & 0.02 & $<0.01$ \\
\hline $\mathrm{LM}$ area daily gain, ${ }^{4} \mathrm{~cm}^{2}$ & 0.170 & 0.165 & 0.179 & 0.157 & 0.151 & 0.184 & 0.0071 & 0.49 & $<0.01$ & $<0.01$ \\
\hline Initial 12 th-rib fat, ${ }^{5} \mathrm{~mm}$ & 2.81 & 2.68 & 2.76 & 2.74 & $2.29^{\mathrm{b}}$ & $3.20^{\mathrm{a}}$ & 0.13 & 0.29 & 0.87 & $<0.01$ \\
\hline Final 12th-rib fat, ${ }^{3} \mathrm{~mm}$ & 4.27 & 3.80 & 3.94 & 4.12 & 3.20 & 4.86 & 0.15 & $<0.01$ & 0.24 & $<0.01$ \\
\hline 12th-rib fat daily gain, ${ }^{3} \mathrm{~mm}$ & 0.026 & 0.020 & $0.021^{\mathrm{b}}$ & $0.025^{\mathrm{a}}$ & 0.016 & 0.030 & 0.0013 & $<0.01$ & $<0.01$ & $<0.01$ \\
\hline
\end{tabular}

a,b Within a row, means without a common superscript letter differ $(P<0.05)$.

${ }^{1} \mathrm{PAP}$ was fed at $3 \mathrm{~g} / \mathrm{d}$ and MON was fed at $300 \mathrm{mg} / \mathrm{d}$.

${ }^{2} \mathrm{GRO}=$ growing; $\mathrm{FNS}=$ finishing.

${ }^{3}$ Interaction between biotype and period $(P=0.001)$.

${ }^{4}$ Interaction between feed additive and period $(P=0.001)$.

${ }^{5}$ Back fat thickness measured on 12th rib.

tured, compound symmetric, heterogeneous compound symmetric, autoregressive of order 1 , heterogeneous first-order autoregressive, toeplitz, heterogeneous toeplitz, and ante-dependence of order 1. The covariance structure that yielded the smaller Akaike and Schwarz's Bayesian criterion based on their -2 restricted log-likelihood was considered to provide the best fit.

Results were considered significant at $P<0.05$. Analyses of variance included initial BW as an initial measurement covariate, which was retained in the model only when it was found to be significant $(P<0.05)$. Tests for normality (Shapiro-Wilk and Kolmogorov-Smirnov) and heterogeneity of treatment variances (GROUP option of SAS) were performed before analyzing the data. Pen was considered the experimental unit in all measurements in this study.

\section{RESULTS}

\section{Feedlot Performance and Carcass Characteristics}

Feedlot performance and carcass characteristics results are presented in Table 2 . No feed additive main effects were detected for the feedlot performance variables and carcass characteristics except for daily DMI expressed in kilograms (DMIKG) or as a percentage of BW (DMIBW), final LM area, and 12th-rib fat daily gain. Bulls receiving PAP had greater DMIKG $(P=$ $0.02)$ and DMIBW $(P<0.01)$ as well as larger $(P=$ $0.02)$ final LM area when compared with bulls receiving MON. However, bulls fed MON presented greater $(P<0.01) 12$ th-rib fat daily gain than those fed PAP. In addition, an interaction between feed additive and period was significant $(P=0.001)$, where no differences for initial LM area in the growing period $(P=0.92)$ were detected; however, bulls receiving PAP presented larger $(P=0.03)$ LM area at the beginning of the finishing period (Fig. 1). Moreover, bulls fed PAP had greater $(P<0.01)$ LM area daily gain during the growing period than bulls fed MON; however, no difference was observed $(P=0.98)$ between bulls receiving PAP and MON during the finishing period (Fig. 1).

Brangus bulls had greater initial and final BW, heavier HCW, increased kidney-pelvic fat in kilograms, and larger initial and final LM areas when compared with Nellore bulls. On the other hand, Nellore bulls had 


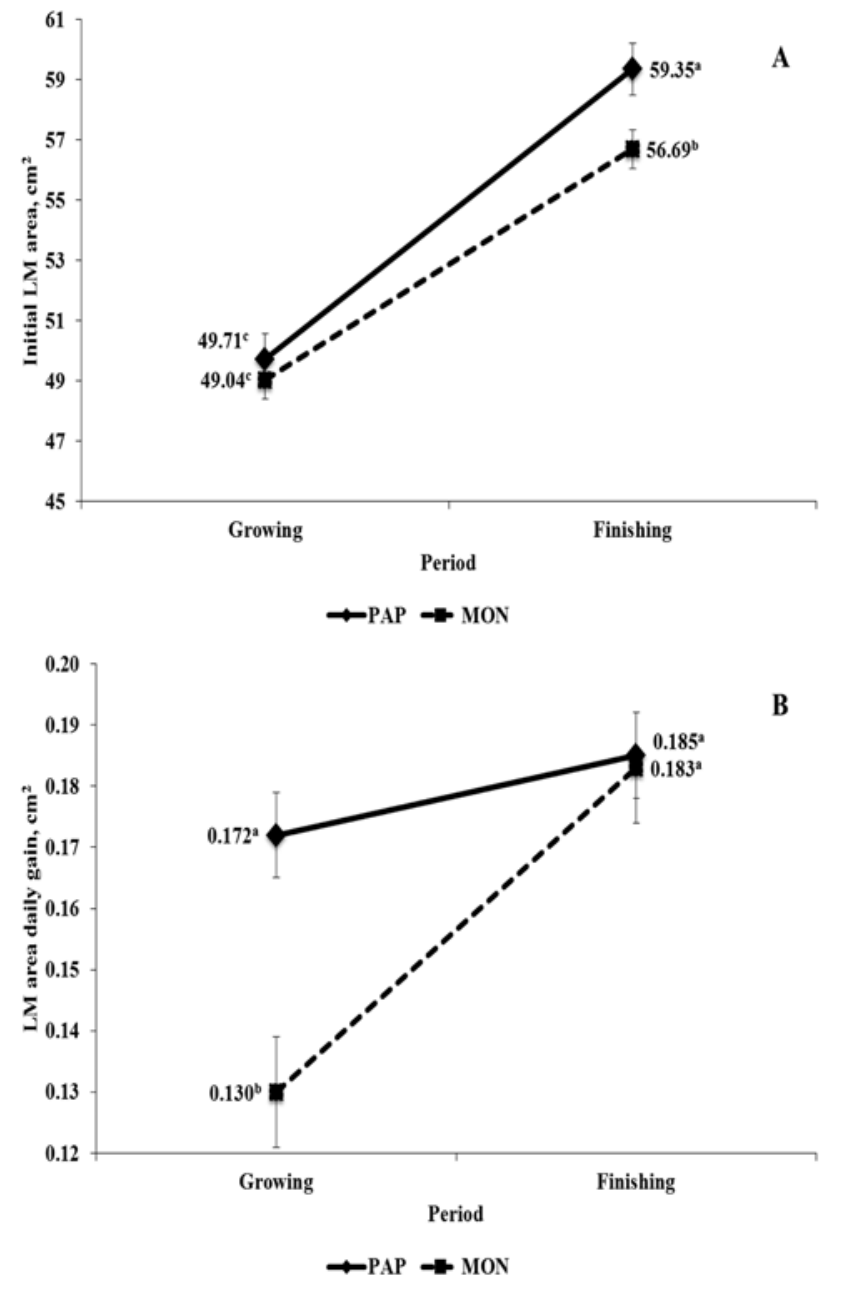

Figure 1. Interaction of feed additive (monensin [MON] or polyclonal antibody preparation [PAP]) with feeding period on initial LM area $(P=0.02$; panel A), and LM area daily gain $(P=0.04$; panel $\mathrm{B})$ of bulls fed high-concentrate diets $(n=24$; pooled SEM $=0.759$ and 0.0083 for panels $\mathrm{A}$ and $\mathrm{B}$, respectively). ${ }^{\mathrm{a}-\mathrm{c}}$ Means without a common superscript letter differ $(P<0.05)$. Error bars represent pooled SEM.

greater daily DMI fluctuation, expressed as a percentage, than Brangus bulls. A significant biotype $\times$ period interaction was found for $\mathrm{ADG}(P=0.01)$, where Brangus bulls maintained ADG that were similar $(P=0.89)$ between the growing and finishing periods but ADG was lower $(P=0.01)$ in the finishing period compared with the growing period for Nellore bulls (Fig. 2A); DMIKG $(P<0.01)$, in which Brangus bulls presented greater $(P<0.01)$ DMIKG than Nellore bulls during the growing period ( 7.48 vs. $6.04 \mathrm{~kg})$ but an even greater difference existed during the finishing period ( 9.24 vs. $6.93 \mathrm{~kg}$; data not shown); DMIBW $(P<0.01)$, where Brangus bulls had greater $(P<0.01)$ DMIBW only during the finishing period (Fig. 2B); final 12th-rib fat $(P<$ $0.01)$, where Brangus bulls presented greater $(P<0.01)$ 12th-rib fat thickness only at the end of the finishing period (Fig. 2C); and 12th-rib fat daily gain $(P<0.01)$, where Brangus bulls had greater $(P<0.01)$ rate of s.c. adipose tissue accretion than Nellore cattle only during the finishing period (Fig. 2D).

\section{Feeding Behavior}

Feeding behavior results are presented in Table 3. A significant biotype $\times$ feed additive interaction was observed $(P=0.03)$ for meals per day, in which Nellore bulls fed MON had $(P<0.05)$ more meals per day $(n=$ 17.1) than Nellore bulls fed PAP $(n=15.1)$ or Brangus bulls fed either MON $(n=15.6)$ or PAP $(n=15.6$; data not shown). No significant feed additive main effects were observed for any of the feeding behavior variables with the exception of meals per day, meal length, and DMI per meal. Bulls receiving PAP had longer meal length $(P=0.04)$ and greater DMI per meal $(P=0.04)$ than bulls receiving MON. An interaction between feed additive and period was observed $(P=0.02)$ for RUM, in which bulls fed MON spent more time ruminating $(P=0.05)$ in the finishing period ( 337 vs. $292 \mathrm{~min})$, but no difference was observed $(P=0.97)$ between bulls receiving MON and PAP during the growing period (467 and $460 \mathrm{~min}$, respectively; data not shown).

Brangus bulls had greater DMI, NDF intake, and DMI per meal and also consumed both DM and NDF faster than Nellore bulls. Significant biotype $\times$ period interactions were observed for EAT $(P=0.04)$, where, compared with Nellore bulls, Brangus bulls spent more time eating $(P=0.05)$ only in the growing period (Fig. 3A); meal length $(P<0.01)$, in which Brangus bulls had $(P=$ $0.04)$ more meals per day than Nellore bulls only in the growing period (Fig. 3C); and DMCR $(P=0.02)$ and NDFCR $(P<0.01)$, where, compared with Nellore bulls, Brangus bulls consumed both DM and NDF faster $(P<$ 0.02 ) in both the growing and the finishing periods, but the difference was larger during the finishing than during the growing phase (Fig. 3B and 3D).

\section{Blood Gas Profiles}

Blood gas profile results are presented in Table 4. Bulls receiving PAP had greater concentrations of $\mathrm{HCO}_{3}, \mathrm{TCO}_{2}, \mathrm{BEB}$, and BEECF than bulls receiving MON. Brangus bulls had greater $(P=0.05)$ concentrations of $\mathrm{HCO}_{3}$ and $\mathrm{TCO}_{2}$ than Nellore bulls.

\section{Blood Lipoprotein Concentrations and Meat Cholesterol}

Lipoprotein concentration results are shown in Table 5. No significant $(P>0.10)$ feed additive main effects or interactions were observed for any of the blood lipoprotein concentration variables with the exception 

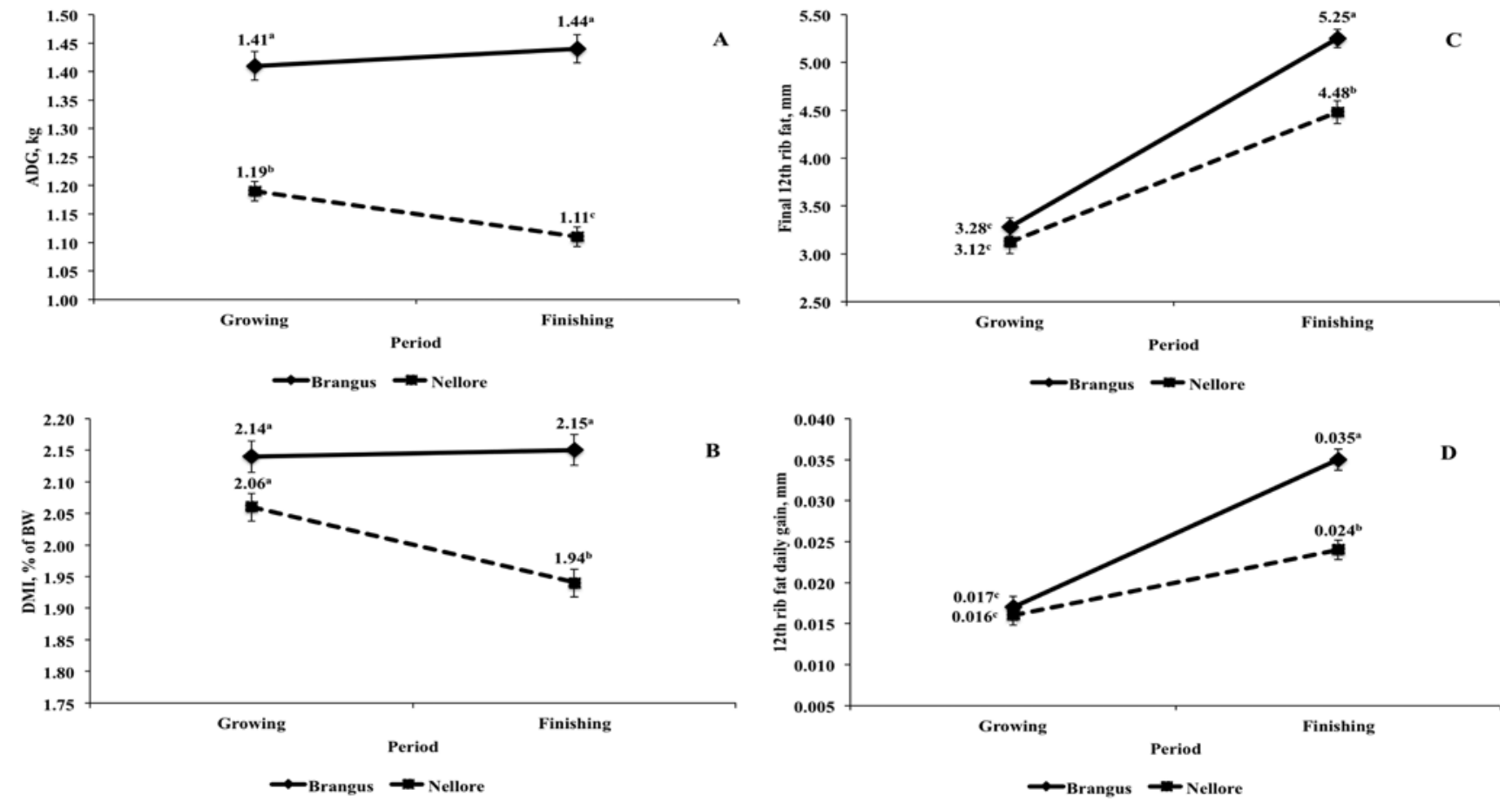

Figure 2. Interaction of biotype (Nellore and Brangus [five-eighths Red Angus and three-eighths Nellore]) during the growing and finishing periods on ADG $(P=0.01$; panel A), DMI expressed as percent of BW $(P=0.008$; panel B), final 12th-rib fat $(P<0.0001$; panel $\mathrm{C})$, and 12th-rib fat daily gain $(P=$ 0.0005 ; panel D) of bulls fed high-concentrate diets $(n=24$; pooled SEM $=0.021$, pooled SEM $=0.023$, pooled SEM $=0.11$, and pooled $\mathrm{SEM}=0.0012$ for panels A, B, C, and D, respectively). a-cMeans without a common superscript letter differ $(P<0.05)$. Error bars represent pooled SEM.

Table 3. Effect of 2 biotypes (Nellore and Brangus [five-eighths Red Angus and three-eighths Nellore]) provided monensin $(\mathrm{MON})$ or polyclonal antibody preparation (PAP) on feeding behavior of yearling beef bulls consuming high-concentrate diets during the growing and finishing periods $(n=24)$

\begin{tabular}{|c|c|c|c|c|c|c|c|c|c|c|}
\hline \multirow[b]{2}{*}{ Variable $^{1}$} & \multicolumn{2}{|c|}{ Biotype (BT) } & \multicolumn{2}{|c|}{ Feed additive $^{2}$ (FA) } & \multicolumn{2}{|c|}{ Period $^{3}$} & \multirow[b]{2}{*}{ SEM } & \multicolumn{3}{|c|}{$P$-value } \\
\hline & Brangus & Nellore & PAP & MON & GRO & FNS & & BT & FA & Period \\
\hline Time spent eating, ${ }^{4} \mathrm{~min} / \mathrm{d}$ & 216.3 & 211.5 & 215.0 & 212.8 & 261.0 & 166.7 & 4.4 & 0.44 & 0.73 & $<0.01$ \\
\hline Time spent ruminating, ${ }^{5} \mathrm{~min} / \mathrm{d}$ & 398.2 & 380.1 & 376.3 & 402.0 & 463.4 & 314.9 & 10.0 & 0.24 & 0.11 & $<0.01$ \\
\hline Time spent resting, $\mathrm{min} / \mathrm{d}$ & 830.5 & 853.4 & 853.8 & 830.2 & $720.4^{b}$ & $963.5^{\mathrm{a}}$ & 12.4 & 0.24 & 0.23 & $<0.01$ \\
\hline Meals per day, ${ }^{6}$ no. & 15.6 & 16.1 & 15.4 & 16.4 & 15.6 & 16.2 & 0.34 & 0.26 & 0.04 & 0.17 \\
\hline DMI, $\mathrm{kg} / \mathrm{d}$ & $8.73^{\mathrm{a}}$ & $6.81^{\mathrm{b}}$ & 7.77 & 7.78 & 7.76 & 7.78 & 0.19 & $<0.01$ & 0.97 & 0.90 \\
\hline NDF intake, $\mathrm{kg}$ & $2.19^{\mathrm{a}}$ & $1.74^{\mathrm{b}}$ & 1.97 & 1.96 & $2.34^{\mathrm{a}}$ & $1.59^{\mathrm{b}}$ & 0.043 & $<0.01$ & 0.85 & $<0.01$ \\
\hline Meal length ${ }^{4}$ min & 14.1 & 13.2 & $14.1^{\mathrm{a}}$ & $13.2^{\mathrm{b}}$ & 17.0 & 10.4 & 0.32 & 0.09 & 0.04 & $<0.01$ \\
\hline DMI per meal, kg & $0.56^{\mathrm{a}}$ & $0.43^{b}$ & $0.51^{\mathrm{a}}$ & $0.47^{\mathrm{b}}$ & $0.51^{\mathrm{a}}$ & $0.48^{\mathrm{a}}$ & 0.014 & $<0.01$ & 0.04 & $<0.01$ \\
\hline $\mathrm{DMCR},{ }^{4} \mathrm{~min} / \mathrm{kg}$ of $\mathrm{DM}$ & 25.06 & 31.10 & 28.29 & 27.86 & 33.83 & 22.32 & 0.72 & $<0.01$ & 0.67 & $<0.01$ \\
\hline $\mathrm{NDFCR},{ }^{4} \mathrm{~min} / \mathrm{kg}$ of $\mathrm{NDF}$ & 97.32 & 124.12 & 112.0 & 109.45 & 112.1 & 109.43 & 3.40 & $<0.01$ & 0.61 & 0.54 \\
\hline DMRR, $\min / \mathrm{kg}$ of DM & $45.78^{\mathrm{b}}$ & $55.79^{\mathrm{a}}$ & 48.98 & 52.59 & $60.31^{\mathrm{a}}$ & $41.26^{\mathrm{b}}$ & 1.53 & $<0.01$ & 0.16 & $<0.01$ \\
\hline NDFRR, $\min / \mathrm{kg}$ of $\mathrm{NDF}$ & $181.16^{\mathrm{b}}$ & $221.84^{\mathrm{a}}$ & 194.39 & 208.61 & 199.71 & 203.29 & 6.33 & $<0.01$ & 0.17 & 0.49 \\
\hline
\end{tabular}

${ }^{\mathrm{a}, \mathrm{b}}$ Within a row, means without a common superscript letter differ $(P<0.05)$.

${ }^{1} \mathrm{DMCR}=\mathrm{DM}$ consumption rate $\mathrm{NDFCR}=\mathrm{NDF}$ consumption rate DMRR $=\mathrm{DM}$ rumination rate NDFRR $=$ NDF rumination rate.

${ }^{2} \mathrm{PAP}$ was fed at $3 \mathrm{~g} / \mathrm{d}$ and $\mathrm{MON}$ was fed at $300 \mathrm{mg} / \mathrm{d}$.

${ }^{3} \mathrm{GRO}=$ growing; FNS $=$ finishing.

${ }^{4}$ Interaction between biotype and period $(P<0.05)$.

${ }^{5}$ Interaction between feed additive and period $(P=0.02)$.

${ }^{6}$ Interaction between biotype and feed additive $(P=0.03)$. 
Table 4. Effect of 2 biotypes (Nellore and Brangus [five-eighths Red Angus and three-eighths Nellore]) provided monensin $(\mathrm{MON})$ or polyclonal antibody preparation (PAP) on blood gas profiles of yearling beef bulls consuming high-concentrate diets during the growing and finishing periods $(n=24)$

\begin{tabular}{|c|c|c|c|c|c|c|c|c|c|c|}
\hline \multirow[b]{2}{*}{ Variable $^{1}$} & \multicolumn{2}{|c|}{ Biotype (BT) } & \multicolumn{2}{|c|}{ Feed additive $^{2}(\mathrm{FA})$} & \multicolumn{2}{|c|}{ Period $^{3}$} & \multirow[b]{2}{*}{ SEM } & \multicolumn{3}{|c|}{$P$-value } \\
\hline & Brangus & Nellore & PAP & $\mathrm{MON}$ & GRO & FNS & & BT & FA & Period \\
\hline$\overline{\text { Blood } \mathrm{pH}}$ & 7.46 & 7.46 & 7.46 & 7.46 & $7.48^{\mathrm{a}}$ & $7.43^{b}$ & 0.013 & 0.48 & 0.75 & $<0.01$ \\
\hline $\mathrm{HCO}_{3}{ }^{-}, \mathrm{mmol} / \mathrm{L}$ & $28.49^{\mathrm{a}}$ & $27.59^{b}$ & $28.85^{\mathrm{a}}$ & $27.23^{b}$ & $29.17^{\mathrm{a}}$ & $26.91^{b}$ & 0.32 & 0.05 & 0.01 & $<0.01$ \\
\hline $\mathrm{TCO}_{2}, \mathrm{mmol} / \mathrm{L}$ & $29.75^{\mathrm{a}}$ & $28.85^{b}$ & $30.17^{\mathrm{a}}$ & $28.43^{\mathrm{b}}$ & $30.38^{\mathrm{a}}$ & $28.22^{\mathrm{a}}$ & 0.32 & 0.05 & $<0.01$ & $<0.01$ \\
\hline $\mathrm{BEB}, \mathrm{mmol} / \mathrm{L}$ & 4.49 & 3.73 & $4.86^{\mathrm{a}}$ & $3.35^{\mathrm{b}}$ & $5.74^{\mathrm{a}}$ & $2.48^{\mathrm{b}}$ & 0.32 & 0.10 & $<0.01$ & $<0.01$ \\
\hline $\mathrm{BEECF}, \mathrm{mmol} / \mathrm{L}$ & 4.37 & 3.67 & $4.74^{\mathrm{a}}$ & $3.30^{\mathrm{b}}$ & $5.36^{\mathrm{a}}$ & $2.68^{\mathrm{b}}$ & 0.32 & 0.13 & $<0.01$ & $<0.01$ \\
\hline
\end{tabular}

a,b Within a row, means without a common superscript letter differ $(P<0.05)$.

${ }^{1} \mathrm{HCO}_{3}-=$ bicarbonates; $\mathrm{TCO}_{2}=$ total $\mathrm{CO}_{2}$ content; $\mathrm{BEB}=$ base excess in whole blood; $\mathrm{BEECF}=$ base excess in extracellular fluid.

${ }^{2} \mathrm{PAP}$ was fed at $3 \mathrm{~g} / \mathrm{d}$ and $\mathrm{MON}$ was fed at $300 \mathrm{mg} / \mathrm{d}$.

${ }^{3} \mathrm{GRO}=$ growing; $\mathrm{FNS}=$ finishing.

of HDL. Bulls receiving PAP had greater concentrations of $\operatorname{HDL}(P=0.04)$ than bulls receiving MON.

Between biotypes, Nellore bulls had greater $(P<$ $0.01)$ concentrations of blood VLDL and triglycerides than Brangus bulls. No main effects of biotype were observed for blood concentrations of cholesterol, HDL, and LDL.

No effects of feed additive $(39.2 \mathrm{mg} / \mathrm{dL}$ for PAP and $36.5 \mathrm{mg} / \mathrm{dL}$ for MON) or of biotype $(35.3 \mathrm{mg} /$ $\mathrm{dL}$ for Brangus and $37.3 \mathrm{mg} / \mathrm{dL}$ for Nellore) were de-
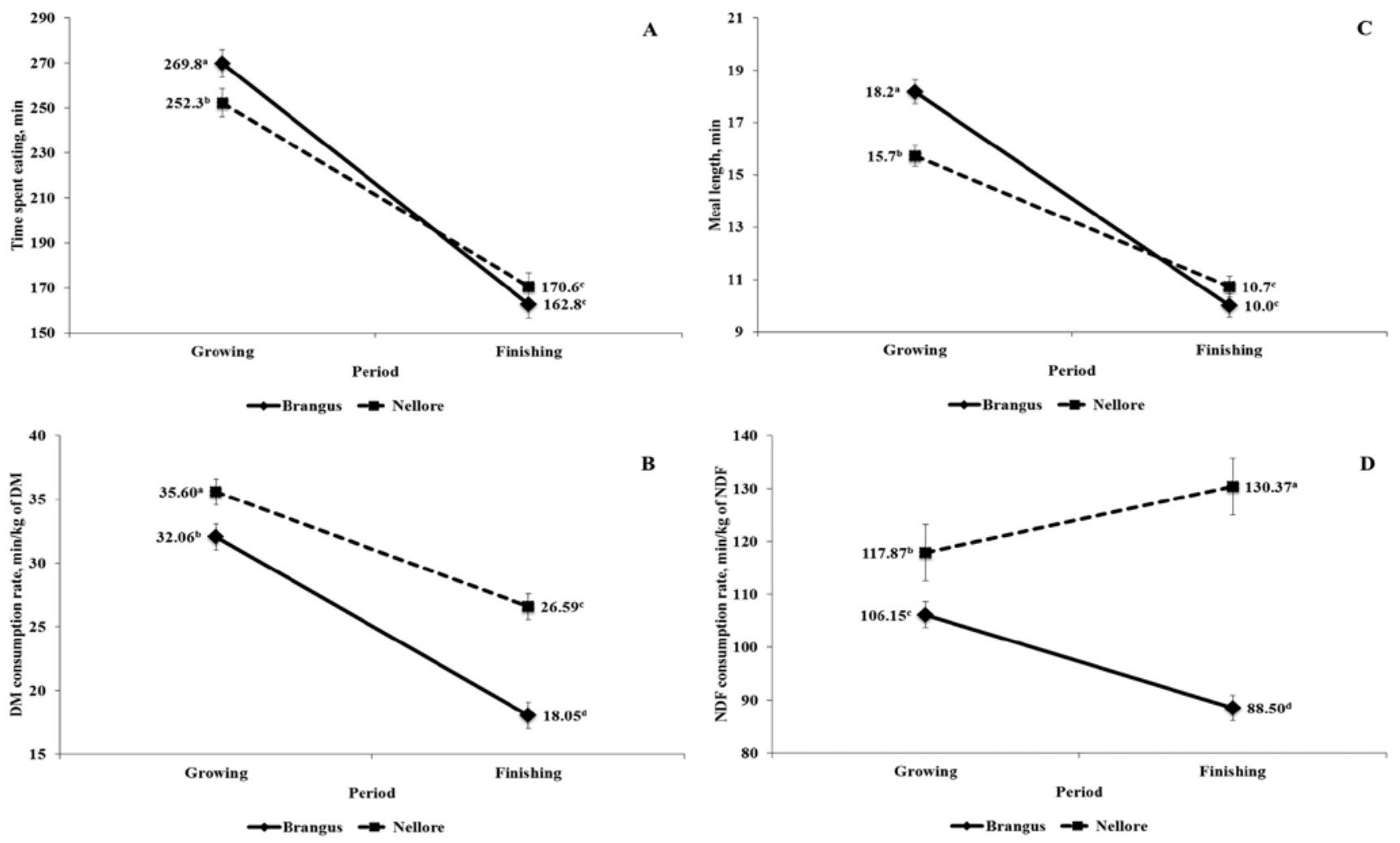

Figure 3. Interaction of biotype (Nellore and Brangus [five-eighths Red Angus and three-eighths Nellore]) during the growing and finishing periods on time spent eating $(P=0.04$; panel A), DM consumption rate $(P=0.02$; panel $\mathrm{B})$, meal length $(P=0.004$; panel $\mathrm{C})$, and NDF consumption rate $(P=$ 0.008 ; panel D) of bulls fed high-concentrate diets $(n=24$; pooled SEM $=6.2$, pooled SEM $=1.02$, pooled SEM $=0.43$, and pooled SEM $=3.88$ for panels A, B, C, and D, respectively). a-dMeans without a common superscript letter differ $(P<0.05)$. Error bars represent pooled SEM. 
Table 5. Effect of 2 biotypes (Nellore and Brangus [five-eighths Red Angus and three-eighths Nellore]) provided monensin $(\mathrm{MON})$ or polyclonal antibody preparation (PAP) on blood lipoproteins concentration of yearling beef bulls consuming high-concentrate diets during the growing and finishing periods $(n=24)$

\begin{tabular}{|c|c|c|c|c|c|c|c|c|c|c|}
\hline \multirow[b]{2}{*}{ Variable $^{1}$} & \multicolumn{2}{|c|}{ Biotype (BT) } & \multicolumn{2}{|c|}{ Feed additive $^{2}$ (FA) } & \multicolumn{2}{|c|}{ Period $^{3}$} & \multirow[b]{2}{*}{ SEM } & \multicolumn{3}{|c|}{$P$-value } \\
\hline & Brangus & Nellore & PAP & $\mathrm{MON}$ & GRO & FNS & & BT & FA & Period \\
\hline Cholesterol, mg/dL & 125.5 & 139.2 & 134.2 & 130.5 & $140.5^{\mathrm{a}}$ & $124.3^{\mathrm{b}}$ & 8.80 & 0.13 & 0.68 & $<0.01$ \\
\hline $\mathrm{HDL}, \mathrm{mg} / \mathrm{dL}$ & 56.9 & 57.0 & $59.9^{\mathrm{a}}$ & $54.0^{\mathrm{b}}$ & 56.9 & 57.0 & 2.92 & 0.98 & 0.04 & 0.99 \\
\hline $\mathrm{LDL}, \mathrm{mg} / \mathrm{dL}$ & 65.2 & 73.0 & 68.3 & 69.8 & $76.6^{\mathrm{a}}$ & $61.5^{\mathrm{a}}$ & 6.48 & 0.37 & 0.87 & $<0.01$ \\
\hline VLDL, mg/dL & $3.37^{\mathrm{b}}$ & $4.58^{\mathrm{a}}$ & 4.09 & 3.86 & 4.16 & 3.79 & 0.42 & 0.01 & 0.48 & 0.66 \\
\hline Triglycerides, mg/dL & $16.8^{\mathrm{b}}$ & $22.9^{\mathrm{a}}$ & 20.4 & 19.3 & 20.8 & 19.0 & 1.52 & 0.01 & 0.46 & 0.66 \\
\hline
\end{tabular}

a,b Within a row, means without a common superscript letter differ $(P<0.05)$.

${ }^{1} \mathrm{HDL}=$ high-density lipoprotein; $\mathrm{LDL}=$ low-density lipoprotein; VLDL = very-low-density lipoprotein .

${ }^{2} \mathrm{PAP}$ was fed at $3 \mathrm{~g} / \mathrm{d}$ and $\mathrm{MON}$ was fed at $300 \mathrm{mg} / \mathrm{d}$.

${ }^{3} \mathrm{GRO}=$ growing; $\mathrm{FNS}=$ finishing.

of feed additive was found for rumenitis scores (1.49 for PAP vs. 2.37 for MON [pooled SEM 0.47]).

\section{Fatty Acid Profile}

The fatty acid compositions of s.c., pelvic, and intermuscular adipose tissues are presented in Table 6. Significant interactions $(P<0.05)$ between biotype and feed additive were observed for myristic acid (14:0), palmitic acid (16:0), oleic acid (18:1), SFA, unsaturat- ed fatty acids (UFA), MUFA, PUFA, and MUFA:SFA ratio. When PAP was fed to Nellore bulls, fat had a higher $(P<0.01)$ proportion of myristic acid (5.39 vs. $4.38 \mathrm{~g} / 100 \mathrm{~g}$ [SEM 0.16] and palmitic acid (28.01 vs. $25.15 \mathrm{~g} / 100 \mathrm{~g}$ [SEM 0.40] but less oleic acid (35.98 vs. $39.75 \mathrm{~g} / 100 \mathrm{~g}$ [SEM 0.42] and a lower MUFA:SFA ratio ( 0.75 vs. 0.88 [SEM 0.02] than Nellore bulls fed MON. However, no differences between feed additives were detected for Brangus bulls for myristic, palmitic, and oleic acids or for the MUFA:SFA ratio. For Nellore

Table 6. Effect of 2 biotypes (Nellore and Brangus [five-eighths Red Angus and three-eighths Nellore]) provided monensin (MON) or polyclonal antibody preparation (PAP) on fatty acid content $(\mathrm{g} / 100 \mathrm{~g})$ from 3 different adipose sites of yearling beef bulls consuming high-concentrate diets $(n=24)$

\begin{tabular}{|c|c|c|c|c|c|c|c|c|c|c|c|}
\hline \multirow[b]{2}{*}{ Fatty acid, $\mathrm{g} / 100 \mathrm{~g}$} & \multicolumn{2}{|c|}{ Biotype (BT) } & \multicolumn{2}{|c|}{ Feed additive $^{1}(\mathrm{FA})$} & \multicolumn{3}{|c|}{ Adipose sites ${ }^{2}(\mathrm{AS})$} & \multirow[t]{2}{*}{$\mathrm{SEM}^{3}$} & \multicolumn{3}{|c|}{$P$-value } \\
\hline & Brangus & Nellore & PAP & MON & s.c. & PELVIC & IM & & BT & FA & $\mathrm{AS}$ \\
\hline $\mathrm{C} 14: 0^{4}$ & 5.09 & 4.88 & 5.22 & 4.75 & $4.37^{b}$ & $5.31^{\mathrm{a}}$ & $5.29^{\mathrm{a}}$ & 0.10 & 0.16 & 0.01 & 0.01 \\
\hline $\mathrm{C} 14: 1$ cis -9 & $1.08^{\mathrm{a}}$ & $0.85^{b}$ & $1.01^{\mathrm{a}}$ & $0.91^{\mathrm{b}}$ & $1.46^{\mathrm{a}}$ & $0.50^{\mathrm{c}}$ & $0.93^{b}$ & 0.044 & $<0.01$ & 0.04 & $<0.01$ \\
\hline $\mathrm{C} 15: 0$ & $1.25^{\mathrm{a}}$ & $1.19^{b}$ & $1.29^{\mathrm{a}}$ & $1.18^{\mathrm{b}}$ & $1.03^{\mathrm{b}}$ & $1.31^{\mathrm{a}}$ & $1.32^{\mathrm{b}}$ & 0.021 & 0.04 & 0.02 & $<0.01$ \\
\hline $\mathrm{C} 16: 0^{4}$ & 27.38 & 26.58 & 27.44 & 26.51 & $26.08^{b}$ & $26.62^{b}$ & $28.24^{\mathrm{a}}$ & 0.30 & 0.07 & 0.03 & $<0.01$ \\
\hline C16:1 trans -9 & $4.19^{\mathrm{a}}$ & $3.64^{b}$ & 3.84 & 3.98 & $5.50^{\mathrm{a}}$ & $2.48^{c}$ & $3.76^{\mathrm{b}}$ & 0.082 & $<0.01$ & 0.27 & $<0.01$ \\
\hline $\mathrm{C} 17: 0$ & 1.77 & 1.76 & 1.77 & 1.76 & $1.52^{\mathrm{b}}$ & $1.89^{\mathrm{a}}$ & $1.88^{\mathrm{a}}$ & 0.032 & 0.85 & 0.79 & $<0.01$ \\
\hline $\mathrm{C} 17: 1$ & 0.80 & 0.79 & $0.77^{b}$ & $0.81^{\mathrm{a}}$ & $0.99^{\mathrm{a}}$ & $0.59^{\mathrm{c}}$ & $0.80^{\mathrm{b}}$ & 0.014 & 0.47 & 0.03 & $<0.01$ \\
\hline C18:0 & $17.63^{b}$ & $19.99^{\mathrm{a}}$ & 18.60 & 19.01 & $12.59^{\mathrm{c}}$ & $25.99^{a}$ & $17.85^{\mathrm{b}}$ & 0.37 & $<0.01$ & 0.44 & $<0.01$ \\
\hline C18: $1^{4}$ & 38.07 & 37.87 & 37.32 & 38.61 & $43.34^{\mathrm{a}}$ & $32.93^{\mathrm{c}}$ & $37.63^{b}$ & 0.37 & 0.71 & 0.02 & $<0.01$ \\
\hline C18:2 & 1.57 & 1.54 & 1.58 & 1.53 & $1.70^{\mathrm{a}}$ & $1.50^{\mathrm{b}}$ & $1.46^{\mathrm{b}}$ & 0.042 & 0.72 & 0.37 & $<0.01$ \\
\hline CLA cis-9 trans-11 & $0.65^{\mathrm{a}}$ & $0.53^{\mathrm{b}}$ & 0.60 & 0.58 & $0.70^{\mathrm{a}}$ & $0.42^{\mathrm{b}}$ & $0.64^{\mathrm{a}}$ & 0.021 & $<0.01$ & 0.37 & $<0.01$ \\
\hline $\mathrm{C} 18: 3$ & $0.161^{\mathrm{b}}$ & $0.170^{\mathrm{a}}$ & $0.162^{b}$ & $0.170^{\mathrm{a}}$ & $0.118^{\mathrm{c}}$ & $0.222^{\mathrm{a}}$ & $0.156^{\mathrm{b}}$ & 0.013 & $<0.01$ & 0.02 & $<0.01$ \\
\hline $\mathrm{SFA}^{4}$ & 53.38 & 54.43 & 54.40 & 53.42 & $45.79^{c}$ & $61.40^{\mathrm{a}}$ & $54.52^{\mathrm{b}}$ & 0.56 & 0.20 & 0.23 & $<0.01$ \\
\hline $\mathrm{UFA}^{4,5}$ & 45.89 & 44.96 & 44.85 & 46.01 & $53.19^{\mathrm{a}}$ & $38.18^{c}$ & $44.92^{b}$ & 0.53 & 0.23 & 0.14 & $<0.01$ \\
\hline MUFA $^{4}$ & 44.14 & 43.26 & 43.08 & 44.32 & $51.33^{\mathrm{a}}$ & $36.49^{c}$ & $43.27^{\mathrm{b}}$ & 0.45 & 0.18 & 0.06 & $<0.01$ \\
\hline PUFA $^{4}$ & 1.73 & 1.72 & 1.75 & 1.71 & $1.83^{\mathrm{a}}$ & $1.73^{b}$ & $1.63^{\mathrm{c}}$ & 0.043 & 0.86 & 0.53 & $<0.01$ \\
\hline MUFA:SFA ${ }^{4}$ & 0.86 & 0.82 & 0.82 & 0.86 & $1.14^{\mathrm{a}}$ & $0.60^{\mathrm{c}}$ & $0.79^{\mathrm{b}}$ & 0.024 & 0.07 & 0.14 & $<0.01$ \\
\hline PUFA:SFA & 0.03 & 0.03 & 0.03 & 0.03 & $0.04^{\mathrm{a}}$ & $0.03^{\mathrm{b}}$ & $0.03^{b}$ & 0.012 & 0.49 & 0.86 & $<0.01$ \\
\hline Unidentified fatty acids & 0.73 & 0.65 & $0.80^{\mathrm{a}}$ & $0.58^{\mathrm{b}}$ & $1.02^{\mathrm{a}}$ & $0.48^{\mathrm{b}}$ & $0.57^{b}$ & 0.053 & 0.45 & $<0.01$ & $<0.01$ \\
\hline
\end{tabular}

${ }^{\mathrm{a}-\mathrm{c} W i t h i n}$ a row, means without a common superscript letter $\operatorname{differ}(P<0.05)$.

${ }^{1} \mathrm{PAP}$ was fed at $3 \mathrm{~g} / \mathrm{d}$ and MON was fed at $300 \mathrm{mg} / \mathrm{d}$.

${ }^{2}$ s.c. $=$ subcutaneous (from LM between 11 th and 12th ribs); IM = intermuscular (between biceps femoris and gluteus medius muscles).

${ }^{3}$ The SEM matches biotype and feed additive means.

${ }^{4}$ Interaction between biotype and feed additive $(P<0.05)$.

${ }^{5} \mathrm{UFA}=$ unsaturated fatty acids. 

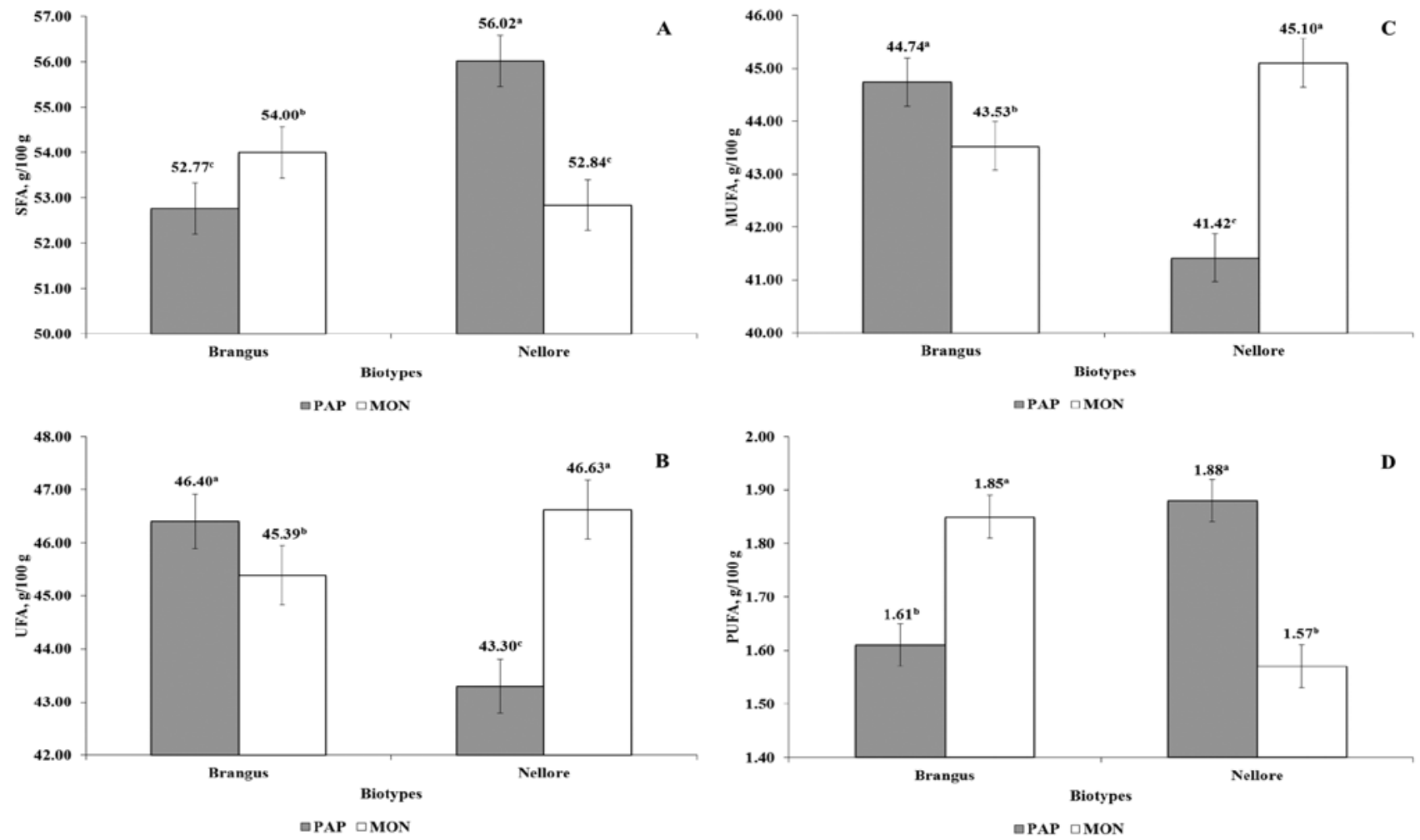

Figure 4. Interaction biotype (Nellore and Brangus [five-eighths Red Angus and three-eighths Nellore]) and feed additive (monensin [MON] or polyclonal antibody preparation [PAP]) on SFA $(P=0.01$; panel A), unsaturated fatty acids (UFA; $P=0.008$; panel B), MUFA $(P=0.0005 ;$ panel C), and PUFA $(P<0.0001$; panel $\mathrm{D})$ from 3 different adipose sites of bulls fed high-concentrate diets $(\mathrm{n}=24$; pooled $\mathrm{SEM}=0.57$, pooled $\mathrm{SEM}=0.53$, pooled $\mathrm{SEM}=0.46$, and pooled $\mathrm{SEM}$ $=0.042$ for panels A, B, C, and D, respectively). ${ }^{\mathrm{a}-\mathrm{c}}$ Means without a common superscript letter differ $(P<0.05)$. Error bars represent pooled SEM.

bulls, a higher $(P<0.05)$ proportion of fat was SFA and PUFA when bulls were fed PAP instead of MON, whereas feeding MON led to greater $(P<0.05)$ SFA and PUFA in fat from Brangus bulls (Fig. 4). Also, fat from Nellore bulls fed PAP had less $(P<0.01)$ UFA and MUFA than Nellore bulls fed MON, whereas fat from Brangus bulls receiving PAP had a greater $(P<$ 0.05 ) content of UFA and MUFA (Fig. 4). Furthermore, bulls fed PAP had greater concentrations of myristoleic acid (14:1 cis-9; $P=0.02)$, pentadecyclic acid $(15: 0 ; P=$ $0.04)$, and unidentified fatty acids $(P<0.01)$ but lower concentrations of heptadecenoic $(17: 1 ; P=0.03)$ and linolenic acid $(18: 3 ; P=0.02)$ than bulls fed MON.

The adipose tissues of Brangus bulls had greater $(P<0.05)$ concentrations of myristoleic acid $(14: 1 \mathrm{cis}-$ $9)$, pentadecyclic acid (15:0), palmitoleic acid (16:1 trans-9), and CLA but lower $(P<0.01)$ concentration of stearic acid (18:0) and linolenic acid (18:3) when compared with the adipose tissues of Nellore bulls.

No interactions between adipose sites and feed additive and between adipose sites and biotype were observed $(P>0.10)$ for any of the fatty acid concentrations evaluated. In general, pelvic fat contained higher concentrations of SFA but lower concentrations of UFA and MUFA when compared with s.c. and intermuscular fat depots.

\section{DISCUSSION}

\section{Feed Additives}

Bulls receiving a spray-dried PAP had feedlot performance that was not different from bulls receiving MON when fed high-concentrate diets. However, LM area daily gain by bulls receiving PAP during the growing period (Fig. 1) was greater than for those fed MON. Considering that $48 \%$ of PAP was active against proteolytic bacteria Clostridium sticklandii (ATCC 12662), Clostridium aminophilum (ATCC 49906), and Peptostreptococcus anaerobius (ATCC 49031), rumen proteolysis may have been reduced when PAP was fed, which would have increased RUP outflow to the small intestine. An increase in supply of postruminal protein during growing, when the RUP requirement is greatest (NRC, 2000), might explain this response. This could explain the larger final LM area of bulls fed PAP and, conversely, the greater 12thrib fat daily gain of bulls receiving MON (Table 2). Bulls fed MON also consumed less DM per meal and spent less time eating per meal, which may have collaborated to increase the number of meals per day in Nellore bulls. The effect of MON on reducing DMI and meal length in cattle fed high-concentrate diets previously has been re- 
ported (Galyean et al., 1992; Erickson et al., 2003; Xu et al., 2014); but, with respect to DMI fluctuations, Pereira et al. (2015) did not observe a significant effect when increasing dose of MON, from 0 to $36 \mathrm{mg} / \mathrm{kg}$, which is in agreement with this study. Pacheco et al. (2012) reported that feedlot performance of bulls was similar for those fed MON or a liquid PAP. Also, DiLorenzo et al. (2008) and Pacheco et al. (2012) reported that dressing percentage was decreased when a liquid PAP was fed, but no feed additive effects on either HCW or dressing percentage was detected in this study. Dressing percentage was less in this study when compared with trials conducted in United States, because Brazilian packing plants do not consider kidney and pelvic fat as carcass components and also require less back fat on the carcasses.

Regarding the blood gas profile, bulls receiving PAP had greater blood buffering capacity than those bulls fed $\mathrm{MON}$, due to increased blood concentrations of $\mathrm{HCO}_{3}$, $\mathrm{TCO}_{2}, \mathrm{BEB}$, and BEECF. Owens et al. (1998) reported that in cattle well adapted to high-concentrate diets, the risk of acidosis and consequent alterations in blood concentration of bicarbonates and blood $\mathrm{pH}$ is low. The absence of significant feed additive effect on blood $\mathrm{pH}$ may be attributed to the fact that bulls fed MON spent more time ruminating in the finishing period, which would have increased rumen-buffering capacity. However, all values related to the blood gas profile reported in this study fall in the range of normal blood status as reported by Carlson (1997). As a result, no significant feed additive main effect was observed for rumenitis score. This indicates that alterations on rumen epithelium were inconsistent when MON was replaced with PAP. Pacheco et al. (2012) previously reported that the rumenitis score of bulls receiving a liquid PAP was less than for bulls receiving MON. Marino et al. (2011), in a study with 9 cannulated Holstein cows, reported that rumen $\mathrm{pH}$ at 4 $\mathrm{h}$ after feeding was not different for cows fed MON or a liquid PAP. The spray-dried PAP is a feed additive with greater specificity when compared with MON. This may explain the numerical reduction in the rumenitis scores and the greater blood buffering capacity shown by bulls fed PAP, which contains $26 \%$ of antibodies being active against Streptococcus bovis (ATCC 9809), which is a primary lactic acid-producing bacteria of ruminants.

The greater concentration of PUFA in adipose tissues of Nellore bulls receiving PAP may be related to the greater blood HDL observed for bulls fed PAP in this study. The HDL are known to transport PUFA from small intestines into bloodstream (Bauchart, 1993; Della Donna et al., 2012), but the effect of spray-dried PAP on blood HDL concentration is still unclear. In general, MON reduces rumen biohydrogenation. Van Nevel and Demeyer (1995) reported that feeding MON inhibited hydrolysis of triacylglycerol and biohydro- genation of UFA in the rumen. As a result, feeding of MON will increase the concentrations of UFA in fat depots (Fellner et al., 1997). Also, the greater incidence of rumen lesions observed in this study for Nellore bulls may have caused an additional negative effect on rumen biohydrogenation (Pacheco et al., 2012) in those animals. Jenkins et al. (2008) reported that rates of lipolysis were reduced when rumen fluid $\mathrm{pH}$ declined below 6.0. This could negatively impact the growth of structural carbohydrate bacteria, which are very $\mathrm{pH}$ sensitive and include some species that act during the biohydrogenation process (Sniffen et al., 1992). On the other hand, as Brangus bulls had lower rumenitis scores, no significant feed additive effect was observed for concentrations of myristic acid (14:0), palmitic acid (16:0), oleic acid (18:1), and MUFA:SFA ratio in adipose tissues of these animals; and besides that, feeding of MON to Brangus bulls led to greater concentrations of SFA and PUFA and lower concentrations of UFA and MUFA when compared with Nellore bulls fed MON.

Pacheco et al. (2012) indicated that liquid PAP did not affect the fatty acid profile of s.c. adipose tissue of bulls when compared with feeding of MON. However, in this study, feeding spray-dried PAP promoted minor changes on the fatty acid profile, such as increasing the PUFA concentrations of adipose tissues of Nellore bulls.

\section{Biotypes}

Compared with Nellore bulls, Brangus had superior feedlot performance and carcass traits. These results may be explained partially by the greater incidence of rumenitis and greater DMI fluctuation of Nellore bulls. Brangus and Nellore bulls had similar DMIBW and 12th-rib fat daily gain in the growing period and a similar G:F throughout the study. Brangus bulls had lower NDFCR in the finishing period than in the growing period; however, Nellore bulls took longer to consume a kilogram of NDF in the finishing period than in the growing period (Fig. 3) and also decreased DMIBW in this period (Fig. 2), which might be a result of greater rumen acidification due to the $85 \%$ concentrate diet fed in this period that increased the incidence of rumenitis and increased DMI fluctuation (10.30 vs. 7.67\%) for Nellore bulls throughout the study. Schwartzkopf-Genswein et al. (2004) reported that DMI fluctuations greater than $10 \%$ might negatively impact feedlot performance. Moreover, Pacheco et al. (2012) fed a finishing diet containing $85 \%$ concentrate to various Bos indicus biotype bulls, and they reported a greater incidence of rumenitis for Nellore bulls than for Canchim (five-eighths Charolais and three-eighths Nellore) and a 3-way cross (one-half Angus, one-fourth Brangus, and one-fourth Nellore). When DMCR and NDFCR of Nellore bulls 
are impaired due to rumen acidification, blood buffering capacity is reduced, and this could negatively impact blood concentrations of $\mathrm{HCO}_{3}$ and $\mathrm{TCO}_{2}$. These factors may explain the greater $\mathrm{ADG}$ and $\mathrm{HCW}$ as well as the greater 12th-rib fat gain in the finishing period of Brangus when compared with Nellore bulls.

When cattle progressed from the growing period to the finishing period, Brangus bulls had accelerated fat deposition; however, the G:F was not negatively altered when compared with Nellore bulls. Nellore bulls may have experienced more rumen acidification when switched to their finishing diet, and their decreased DMI and ADG could have delayed and reduced fat deposition, as biotype did not affect LM area daily gain. In addition, the improved feedlot performance of Brangus bulls relative to Nellore may be explained partially by genetic selection of British cattle for greater DMI potential. This could explain the greater DMI per meal by Brangus bulls and, consequently, their greater $\mathrm{ADG}$ and nutrient requirements for maintenance (NRC, 2000). Given the reduced DMI by Zebu cattle $(6.62 \mathrm{~kg}$ for Nellore fed PAP, $6.36 \mathrm{~kg}$ for Nellore fed MON, $8.58 \mathrm{~kg}$ for Brangus fed PAP, and $8.13 \mathrm{~kg}$ for Brangus fed MON), which may be related to a combined effect of increased rumen acidification and lower nutrient requirements for maintenance, their CP intake may limit growth performance (Millen et al., 2009), because ruminal escape of dietary protein and efficiency of microbial protein synthesis are reduced when DMI is reduced, but this concept needs further study. Differences in mature BW of Brangus and Nellore bulls (Owens et al., 1995) might further explain differences in fat deposition among biotypes. A greater dressing percentage was expected for Nellore than for Brangus bulls because that was reported previously (Koch et al., 1982; Sherbeck et al., 1995; Pacheco et al., 2012). However, because Nellore bulls had lower DMI and 12th-rib fat daily gain during the finishing period, their carcasses had less 12thrib fat than Brangus bulls (4.48 vs. 5.25 mm; Fig. 2), which would negatively impact dressing percentage.

With respect to fatty acid profile in adipose tissues, relevant variables were discussed in the previous section because of the interactions observed between biotype and feed additive. However, it is noteworthy to mention that the main effect of biotype with a greater concentration of stearic acid (18:0) in the adipose tissues of Nellore bulls appears more responsible for changes in SFA, MUFA, and UFA concentrations than the main effect of biotype on increasing concentrations of myristoleic acid (14:1 cis-9), pentadecyclic acid (15:0), palmitoleic acid (16:1 trans-9), and CLA in Brangus bulls. Fatty acid $\Delta 9$ desaturase is responsible for converting SFA to MUFA in animal tissues, and its activity could be genetically controlled (Bartoň et al., 2010; Brugiapaglia et al., 2014). This could partially explain the differences in fatty acid profiles between biotypes in this study. Feeding MON as well as the greater incidence of rumen lesions may have reduced rumen biohydrogenation by Nellore bulls. The effect of biotype on stearic acid (18:0) may be related to increased de novo fatty acid synthesis; however, that theory needs further study.

\section{Sites of Fat Deposition}

Concentrations of SFA were greater in pelvic fat samples than in s.c. or intermuscular fat. Waldman et al. (1968) reported that the concentration of SFA increased from external to internal fat locations. Also, the higher concentrations of SFA and 18:0 suggest that rates of de novo fatty acid synthesis were greater in pelvic adipose tissue than in other fat depots (Kerth et al., 2015). On the other hand, the higher concentrations of UFA, MUFA, and PUFA in s.c. adipose tissue may be related to its development from brown adipose tissue that is rich in MUFA (Chen et al., 2007). Differences in the fatty acid profiles observed from different fat depots in this study are not easily explained. Further investigation is needed to determine the factors responsible for the differences in fatty acid profile among various adipose sites.

\section{Conclusions}

Brangus bulls had slightly faster and more efficient gains than Nellore bulls when fed feedlot diets. Further research is needed to examine the sensitivity of Zebu cattle to high-concentrate diets and their greater incidence of rumenitis. The fatty acid profile was affected, in general, by the interaction of biotype and feed additive, which deserves further research as well.

Feeding a spray-dried PAP led to feedlot performance of bulls similar to feeding MON. Feeding a spray-dried PAP may provide an alternative feed additive with potential to replace ionophores.

\section{LITERATURE CITED}

Allain, C. C., L. C. Poon, C. S. G. Chan, W. Richmond, and P. C. Fu. 1974. Enzymatic determination of total serum cholesterol. Clin. Chem. 20(4):470-475.

Anassori, E. A., B. D. Naghadeh, R. Pirmohammadi, A. Taghizadeh, S. Asri-Rezaei, M. Maham, S. Farahmand-Azar, and P. Farhoomand. 2011. Garlic: A potential alternative for monensin as a rumen modifier. Livest. Sci. 142:276-287. doi:10.1016/j.livsci.2011.08.003.

AOAC. 1990. Official methods of analysis. 15th ed. Assoc. Off. Anal. Chem., Arlington, VA.

AOAC. 1995. Official methods of analysis. 16th ed. AOAC Int., Gaithersburg, MD. 
AOAC. 1997. Official methods of analysis. 16th ed. AOAC Int., Arlington, VA.

Bartoň, L., T. Kott, D. Bureš, D. Řehák, R. Zahrádková, and B. Kottová. 2010. The polymorphisms of stearoyl-CoA desaturase (SCD1) and sterol regulatory element binding protein-1 (SREBP-1) genes and their association with the fatty acid profile of muscle and subcutaneous fat in Fleckvieh bulls. Meat Sci. 85:15-20. doi:10.1016/j.meatsci.2009.11.016.

Bauchart, D. 1993. Lipid absorption and transport in ruminants. J. Dairy Sci. 76:3864-3881. doi:10.3168/jds.S0022-0302(93)77728-0.

Bevans, D. W., K. A. Beauchemin, K. S. Schwartzkopf-Genswein, J. J. McKinnon, and T. A. McAllister. 2005. Effect of rapid or gradual grain adaptation on subacute acidosis and feed intake by feedlot cattle. J. Anim. Sci. 83:1116-1132.

Bigham, M. L., and W. R. McManus. 1975. Whole wheat grain feeding of lambs. Effects of roughage and wheat grain mixtures. Aust. J. Agric. Res. 26:1053-1062. doi:10.1071/AR9751053.

Blanch, M., S. Calsamiglia, N. DiLorenzo, A. DiCostanzo, S. Muetzel, and R. J. Wallace. 2009. Physiological changes in rumen fermentation during acidosis induction and its control using a multivalent polyclonal antibody preparation in heifers. J. Anim. Sci. 87:1722-1730. doi:10.2527/jas.2008-1184.

Bohac, C. E., K. S. Rhee, H. R. Cross, and K. Ono. 1988. Assessment of methodologies for colorimetric cholesterol assay of meats. J. Food Sci. 53:1642-1644. doi:10.1111/j.1365-2621.1988.tb07804.x.

Brink, D. R., S. R. Lowry, R. A. Stock, and J. C. Parrot. 1990. Severity of liver abscesses and efficiency of feed utilization of feedlot cattle. J. Anim. Sci. 68:1201-1207.

Brossard, L., C. Martin, and B. Michalet-Doreau. 2003. Ruminal fermentative parameters and blood acid-basic balance changes during the onset and recovery of induced latent acidosis in sheep. Anim. Res. 52:513-530. doi:10.1051/animres:2003036.

Brugiapaglia, A., C. Lussiana, and G. Destefanis. 2014. Fatty acid profile and cholesterol content of beef at retail of Piemontese, Limousin and Friesian breeds. Meat Sci. 96:568-573. doi:10.1016/j.meatsci.2013.08.012.

Carlson, G. P. 1997. Fluid, electrolyte and acid-base balance. In: J. J. Kaneko, editor, Clinical biochemistry of domestic animals. 5th ed. Academic Press, New York, NJ. p. 485-516.

Castillo, C., J. L. Benedito, J. Méndez, V. Pereira, M. López-Alonso, M. Miranda, and J. Hernandéz. 2004. Organic acids as a substitute for monensin in diets for beef cattle. Anim. Feed Sci. Technol. 115:101-116. doi:10.1016/j.anifeedsci.2004.02.001.

Chen, C., G. E. Carstens, C. D. Gilbert, C. M. Theis, S. L. Archibeque, M. W. Kurz, L. J. Slay, and S. B. Smith. 2007. Dietary supplementation of high levels of saturated/monounsaturated fatty acids to ewes during late gestation reduces thermogenesis in newborn lambs by depressing fatty acid oxidation in perirenal brown adipose tissue. J. Nutr. 137:43-48.

CONCEA. 2013. Diretriz brasileira para o cuidado e a utilização de animais para fins científicos e didáticos. http://www.mct. gov.br/upd blob/0234/234054.pdf. (Accessed 21 June 2015)

Della Donna, L., S. Bassilian, P. Souda, C. Nebbia, J. P. Whitelegge, and D. L. Puppione. 2012. Mass spectrometric measurements of the apolipoproteins of bovine (Bos taurus) HDL. Comp. Biochem. Physiol., Part D: Genomics Proteomics 7:9-13. doi:10.1016/j.cbd.2011.10.001.

DiLorenzo, N., C. R. Dahlen, F. Diez-Gonzalez, G. C. Lamb, J. E. Larson, and A. DiCostanzo. 2008. Effects of feeding polyclonal antibodies preparations on rumen fermentation patterns, performance, and carcass characteristics of feedlot steers. J. Anim. Sci. 86:3023-3032. doi:10.2527/jas.2007-0859.
DiLorenzo, N., F. Diez-Gonzalez, and A. DiCostanzo. 2006. Effects of feeding polyclonal antibody preparations on ruminal bacterial populations and ruminal $\mathrm{pH}$ of steers fed high-grain diets. J. Anim. Sci. 84:2178-2185. doi:10.2527/jas.2005-489.

Erickson, G. E., C. T. Milton, K. C. Fanning, R. J. Cooper, R. S. Swingle, J. C. Parrott, G. Vogel, T. J. Klopfenstein. 2003. Interaction between bunk management and monensin concentration on finishing performance, feeding behavior, and ruminal metabolism during an acidosis challenge with feedlot cattle. J. Anim. Sci. 81:2869-2879.

European Parliament, Council of the European Union. 2003. Regulation (EC) no. 1831/2003 of the European Parliament and the Council on additives for use in animal nutrition. Off. J. Eur. Union: Legis. 268:29-43.

Fellner, V., F. D. Sauer, and J. K. G. Kramer. 1997. Effect of nigercin, monensin, and tetronasin on biohydrogenation in continuous flow-through ruminal fermenters. J. Dairy Sci. 80:921-928. doi:10.3168/jds.S0022-0302(97)76015-6.

Folch, J., M. Lees, and G. H. Sloane-Stanley. 1957. A simple method for the isolation and purification of total lipids from animal tissues. J. Biol. Chem. 226:497-509.

Galyean, M. L., K. F. Malcolm, and G. C. Duff. 1992. Performance of feedlot steers fed diets containing laidlomycin propionate or monensin plus tylosin, and effects of laidlomycin propionate concentration on intake patterns and ruminal fermentation in beef steers during adaptation to a high concentrate diet. J. Anim. Sci. 70:2950-2958.

Gill, H. S., Q. Shu, and R. A. Leng. 2000. Immunization with Streptococcus bovis protects against lactic acidosis in sheep. Vaccine 18:2541-2548. doi:10.1016/S0264-410X(00)00017-7.

Jenkins, T. C., R. J. Wallace, P. J. Moate, and E. E. Mosley. 2008. Board-invited review: Recent advances in biohydrogenation of unsaturated fatty acids within the rumen microbial ecosystem. J. Anim. Sci. 86:397-412. doi:10.2527/jas.2007-0588.

Kerth, C. R., A. L. Harbison, S. B. Smith, and R. K. Miller. 2015. Consumer sensory evaluation, fatty acid composition, and shelf life of ground beef with subcutaneous fat trimmings from different carcass locations. Meat Sci. 104:30-36. doi:10.1016/j.meatsci.2015.01.014.

Koch, R. M., M. E. Dikeman, and L. V. Cundiff. 1982. Characterization of biological types of cattle (cycle III). V. Carcass wholesale cut composition. J. Anim. Sci. 54:1160-1168.

Marino, C. T., W. G. Otero, P. H. M. Rodrigues, A. DiCostanzo, D. D. Millen, R. L. D. Pacheco, N. DiLorenzo, C. L. Martins, and M. D. B. Arrigoni. 2011. Effects of adding polyclonal antibody preparations on ruminal fermentation patterns and digestibility of cows fed different energy sources. J. Anim. Sci. 89:3228-3235. doi:10.2527/jas.2010-3062.

Meyer, N. F., G. E. Erickson, T. J. Klopfenstein, M. A. Greenquist, M. K. Luebbe, P. Williams, and M. A. Engstrom. 2009. Effect of essential oils, tylosin, and monensin on finishing steer performance, carcass characteristics, liver abscesses, ruminal fermentation, and digestibility. J. Anim. Sci. 87:2346-2354. doi:10.2527/jas.2008-1493.

Millen, D. D., R. D. L. Pacheco, M. D. B. Arrigoni, M. L. Galyean, and J. T. Vasconcelos. 2009. A snapshot of management practices and nutritional recommendations used by feedlot nutritionists in Brazil. J. Anim. Sci. 87:3427-3439. doi:10.2527/jas.2009-1880.

Noci, F., F. J. Monahan, P. French and A. P. Moloney. 2005. The fatty acid composition of muscle fat and subcutaneous adipose tissue of pasture-fed beef heifers: Influence of the duration of grazing. J. Anim. Sci. 83:1167-1178.

NRC. 2000. Nutrient requirements of beef cattle. 7th ed. Natl. Acad. Press, Washington, DC. 
Owens, F. N., D. R. Gill, D. S. Secrist, and S. W. Coleman. 1995. Review of some aspects of growth and development of feedlot cattle. J. Anim. Sci. 73:3152-3172.

Owens, F. N., D. S. Secrist, W. J. Hill, and D. R. Gill. 1998. Acidosis in cattle: A review. J. Anim. Sci. 76:275-286.

Pacheco, R. D. L., D. D. Millen, N. DiLorenzo, C. L. Martins, C. T. Marino, M. V. Fossa, S. L. Beier, A. DiCostanzo, P. H. M. Rodrigues, and M. D. B. Arrigoni. 2012. Effects of feeding a multivalent polyclonal antibody preparation on feedlot performance, carcass characteristics, rumenitis, and blood gas profile in Bos indicus biotype yearling bulls. J. Anim. Sci. 90:1898-1909. doi:10.2527/jas.2010-3521.

Pereira, M. C. S., T. V. B. Carrara, J. Silva, D. P. Silva, D. H. M. Watanabe, L. A. Tomaz, M. D. B. Arrigoni, and D. D. Millen. 2015. Effect of different doses of sodium monensin on feeding behavior, dry matter intake variation and selective consumption of feedlot Nellore cattle. Anim. Prod. Sci. 55:170 173. doi:10.1071/AN14306.

Perkins, T. L., R. D. Green, and K. E. Hamlin. 1992. Evaluation of ultrasonic estimates of carcass fat thickness and longissimus muscle area in beef cattle. J. Anim. Sci. 70:1002-1010.

Robles, V., L. A. González, A. Ferret, X. Manteca, and S. Calsamiglia. 2007. Effects of feeding frequency on intake, ruminal fermentation, and feeding behavior in heifers fed high-concentrate diets. J. Anim. Sci. 85:2538-2547. doi:10.2527/jas.2006-739.

Schwartzkopf-Genswein, K. S., K. A. Beauchemin, T. A. McAllister, D. J. Gibb, M. Streeter, and A. D. Kennedy. 2004. Effect of feed delivery fluctuations and feeding time on ruminal acidosis, growth performance, and feeding behavior of feedlot cattle. J. Anim. Sci. 82:3357-3365.
Sherbeck, J. A., J. D. Tatum, T. G. Field, J. B. Morgan, and G. C. Smith. 1995. Feedlot performance, carcass traits, and palatability traits of Hereford and Hereford $\times$ Brahman steers. J. Anim. Sci. 73:3613-3620.

Shu, Q., H. S. Gill, D. W. Hennessy, R. A. Lang, S. H. Bird, and J. B. Rowe. 1999. Immunization against lactic acidosis in cattle. Res. Vet. Sci. 67:65-71. doi:10.1053/rvsc.1998.0284.

Shu, Q., H. S. Gill, J. B. Leng, and J. B. Rowe. 2000. Immunization with a Streptococcus bovis vaccine administered by different routes against lactic acidosis in sheep. Vet. J. 159:262-269. doi:10.1053/tvj1.1999.0400.

Sniffen, C. J., J. D. O'Connor, P. J. Van Soest, D. G. Fox, and J. B. Russell. 1992. A Net Carbohydrate and Protein System for evaluating cattle diets: II. Carbohydrate and protein availability. J. Anim. Sci. 70:3562-3577.

Van Nevel, C. J., and I. Demeyer. 1995. Lipolysis and biohydrogenation of soybean oil in the rumen in vitro: Inhibition by antimicrobials. J. Dairy Sci. 78:2797-2806.

Waldman, R. C., G. C. Suess, and V. H. Brundgardt. 1968. Fatty acids of certain bovine tissues and their association with growth, carcass, palatability traits. J. Anim. Sci. 27:632-635.

Xu, L., M. L. He, R. F. Liang, T. A. McAllister, and W. Z. Yang 2014. Effects of grain source and monensin level on growth performance, carcass traits and fatty acid profile in feedlot beef steers. Anim. Feed Sci. Technol. 198:141-150. doi:10.1016/j.anifeedsci.2014.10.015. 